\title{
Studi Kasus Penerapan PSAK 23 dalam Pengakuan Pendapatan pada PT G
}

\author{
Tri Ariani Wahyu Vitaningsih 1 \\ Pendidikan Akuntansi FKIP \\ Universitas PGRI Madiun, Indonesia \\ Email: triarianiwahyu06@gmail.com
}

\author{
Satrijo Budiwibowo² \\ Pendidikan Akuntansi FKIP \\ Universitas PGRI Madiun, Indonesia
}

\author{
Elly Astuti ${ }^{3}$ \\ Pendidikan Akuntansi FKIP \\ Universitas PGRI Madiun, Indonesia
}

\begin{abstract}
ABSTRAK
Penelitian dilakukan untuk mengetahui penerapan PSAK 23 Revisi 2018 dalam pengakuan pendapatan pada PT G. Jenis penelitian ini adalah penelitian kualitatif studi kasus. Pengumpulan data dilakukan dengan dokumentasi hasil wawancara dari media sosial, berita bisnis terkait, PSAK revisi 2018 serta peraturan perundangan yang berlaku. Analisis data dilakukan dengan pembandingan PSAK, Laporan Keuangan Perusahaan dan Berita Bisnis terkait kasus PT.G. Hasil penelitian menunjukkan bahwa laporan keuangan PT G belum sepenuhnya mematuhi regulasi terkait penyusunan laporan keuangan. Faktor penyebab ketidaksesuaian adalah adanya konflik kepentingan dalam manajemen PT G.
\end{abstract}

Kata Kunci: PSAK 23; Pengakuan Pendapatan; Kecukupan Regulasi Akuntansi; Konfli Kepentingan.

\section{Case Study Implementation of PSAK 23 in Revenue Recognition at PT. G}

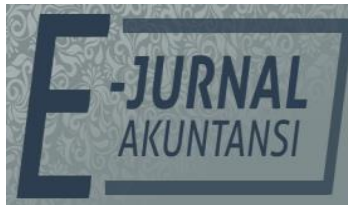

\section{ABSTRACT}

The study was conducted to determine the application of PSAK 232018 Revision in recognition of income at PT G. This type of research is a qualitative case study research. Data collection was carried out by documenting the results of interviews from social media, related business news, the revised PSAK 2018 and the applicable laws and regulations. Data analysis was performed by comparing PSAK, Corporate Financial Reports and Business News related to the case of PT.G. The results showed that PT G's financial statements have not fully complied with regulations related to the preparation of financial statements. The factor causing the discrepancy is the existence of a conflict of interest in the management of PT G.

Keywords: PSAK 23; Revenue Recognition; Adequacy Of Accounting Regulations; Conflict Of Interest. 


\section{PENDAHULUAN}

Salah satu aspek penting dalam penilaian kinerja keuangan perusahaan adalah komponen pendapatan. Banyak rasio-rasio penilaian keuangan yang menggunakan komponen pendapatan sebagai dasar diantaranya ROE, ROI, ROA, EVA dan lain-lain. Untuk itu pengakuan pendapatan menjadi perhatian utama beberapa dekade terakhir karena banyak skandal dalam penyusunan laporan keuangan yang melakukan pengakuan pendapatan prematur. Beberapa skandal terkait penyusunan laporan keuangan diantaranya; PT. Kimia Farma, Olympus, Toshiba, Volkswagen, Worldcom, Enron dan lain-lain. Untuk itu beberapa regulasi akuntansi difokuskan untuk membahas kriteria pengakuan pendapatan.

Regulasi akuntansi mengenai pengakuan pendapatan dituangkan dalam PSAK 23. PSAK 23 mengatur kriteria pengakuan pendapatan pada tiga kejadian yaitu: Penjualan barang, penjualan jasa, dan penggunaan aset entitas oleh pihak lain yang menghasilkan bunga, royalti dan dividen (Ikatan Akuntan Indonesia, 2018). Namun demikian, masih ada perusahaan yang mencari celah atas penerapan regulasi yang telah ada, dengan menerapkan praktik akuntansi kreatif.

Akuntansi kreatif merupakan distorsi penyampaian pesan keuangan yang diakibatkan oleh aktivitas penyusun laporan keuangan (Gowthorpe \& Amat, 2005). Praktik akuntansi kreatif ini sebenarnya tidak sesuai dengan etika profesional akuntan. Goel (2019) menjelaskan bahwa praktik akuntansi yang beretika merujuk pada penyusunan laporan keuangan perusahaan yang adil dan transparan tanpa adanya praktik akuntansi kreatif. Beberapa praktik akuntansi kreatif yang tidak beretika diantarnyanya adalah: penyalahgunaan aset, pengakuan pendapatan prematur, channel stuffing, dan cookie jar reserves.

Salah satu praktik pengakuan pendapatan prematur yang terjadi di Indonesia adalah Kasus PT. G yang merupakan salah satu perusahaan penerbangan Indonesia. Kasus PT G ini berawal dari Rapat Umum Pemegang Saham Tahunan yang mengumumkan kinerja keuangan tahun 2018 mencatat laba bersih US\$ 809,85 ribu atau setara Rp 11,33 miliar (kurs Rp 14.000) (Simorangkir, 2019). Akan tetapi dua komisaris PT G tidak setuju dengan pencatatan laporan keuangan PT G pada tahun 2018 (Puranidhi, 2019). Kedua komisaris menolak menandatangani laporan keuangan karena transaksi kerjasama yang dilakukanantara PT G dan PT M belum bias diakui sebagai pendapatan karena dapat menimbulkan kerancuan dan menyesatkan dikarenakan perusahaan yang sebelumnya mengalami rugi mendadak untung besar (Pratiwi, 2019). Akan tetapi Menurut Direktur Keuangan \& Manajemen Risiko PT G, secara substansi pengakuan pendapatan sebelum kas diterima tidak melanggar Pernyataan Standar Akuntansi Keuangan (PSAK) 23 (Ibrahim \& Binekasri, 2019)

Berkaitan dengan masalah perbedaan pengakuan antara manajemen dan komisaris menjadi alasan terbentuknya konflik kepentingan. Faktor tersebut dituangkan dalam teori keagenan. Teori keagenan memberikan asumsi bahwa setiap orang memiliki motivasi untuk kepentingannya sendiri sehingga mengakibatkan konflik kepentingan. Hal ini memberikan dasar bagi manajer untuk menciptakan konflik keagenan guna mengupayakan keuntungan pribadi 
dari pada memaksimalkan nilai pemegang saham, sehingga terjadi perbedaan prospek pemilik dan kepentingan manajer atau bias dikatakan konflik yang digariskan oleh teori klasik mereka tentang pemisahan kepemilikan dari control (Javaid \& Javid, 2017)

Berdasarkan latar belakang tersebut, Kasus pengakuan pendapatan di PT. G yang merupakan salah satu BUMN menjadi menarik untuk diteliti. Apakah kebijakan akuntansi yang dipilih utamanya dalam pengakuan pendapatan sudah sesuai dengan PSAK 23 revisi 2018.

\section{METODE PENELITIAN}

Penelitian termasuk jenis penelitian kualitatif studi kasus. Pengumpulan data dilakukan dengan dokumentasi hasil wawancara dari media sosial (youtube), berita bisnis terkait (Tempo, Liputan6, Detik.Com, CNN Indonesia, Kumparan.com, Kata Data, Suara.com, CNBC Indonesia, web Otoritas Jasa Keuangan, web Kementrian Keuangan Indonesia), PSAK 23 revisi 2018 (Paragraf 28, 29, dan 30) serta peraturan perundangan yang berlaku (UU RI No.5 tahun 2011 tentang Akuntan Publik, Undang-Undang Nomor 8 Tahun 1995 tentang Pasar Modal, Peraturan Bapepamdan LK Nomor VIII.G.7 tentang Penyajian dan Pengungkapan Laporan Keuangan Emiten dan Perusahaan Publik, Peraturan Bapepam Nomor VIII.G.11 tentang Tanggung Jawab Direksi atas Laporan Keuangan).

Analisis data dilakukan dengan model (Miles \& Huberman, 1994) dimana kegiatan reduksi data, penyajian data dan penarikan kesimpulan dilakukan secara bersamaan. Data dari laporan keuangan PT. G disandingkan dengan PSAK 23 dan perkembangan berita bisnis PT. G. Data-data dari berita bisnis akan digunakan sebagai pelengkap informasi non finansial yang mempengaruhi kebijakan akuntansi PT. G. Adapun beberapa berita bisnis yang pada akhirnya digunakan sebagai informasi non finansial dalam penelitian ini adalah berita mengenai kesepakatan kontrak kerjasama antara PT. A dan PT. G, hasil wawancara auditor PT. G, wawancara manajemen PT. A dan manajemen PT. G. Data-data pelengkap non finansial tersebut kemudian dibandingkan dengan catatan atas laporan keuangan PT. G. Hal ini untuk mendukung validitas dan reliabilitas data yang digunakan sebagai acuan analisis. Konsistensi pernyataan tersebut kemudian dibandingkan dengan standar regulasi yang ada dalam PSAK 23. Apakah perlakuan terhadap pengakuan pendapatan PT. G sudah memenuhi kaidah akuntansi berlaku umum atau belum. Setelah itu dilakukan penarikan kesimpulan.

\section{HASIL DAN PEMBAHASAN}

PTG pada tahun buku 2018 berhasil melaporkan kinerja keuangannya dalam keadaan laba sebesar U\$D809 ribu, padahal di tahun 2017 perseroan tersebut masih mengalami rugi sebesar U\$D216,28 juta. Namun keadaan tersebut justru menjadi polemik karena dua komisaris PTG, CT dan DO menolak menandatangani laporan keuangan tahun 2018 PT G. Penolakan tersebut dikarenakan adanya pencatatan transaksi atas perjanjian kerjasama yang dilakukan oleh PT G dan PT M terkait penyediaan pelayanan wifi dan hiburan dalam pesawat dan manajemen konten yang telah dicatat pada pos pendapatan pada tahun 2018. Padahal hingga akhir tahun 2018 belum ada pembayaran yang diterima 
oleh PT G, di mana dalam perjanjian tersebut telah disebutkan bahwa pada bulan Oktober saat penandatangan kontrak seharusnya PT G telah menerima pembayaran.

Berdasarkan hasil analisis dan didukung dengan bukti penolakan komisaris dan pendapat informan menunjukkan bahwa kontrak perjanjian antara PT G dan PT M belum bisa diakui sebagai pendapatan. Sekjen Kemenkeu H menyatakan bahwa "Kesimpulannya ada dugaan yang berkaitan dengan pelaksanaan audit itu belum sepenuhnya mengikuti standar yang berlaku"(Muslimawati, 2019). Adapun juga pendapat dari anggota 1 Badan Pemeriksa Keuangan, AFS mengungkapkan, "Secaraumum memang kami melihat ada dugaan kuat terjadifinancial enginering, rekayasan keuangan," (Hendartyo, 2019). Selain itu juga pendapat Menteri Keuangan SMI menyebutkan bahwa, "Sekarang, setelah pertemuan dengan Otoritas Jasa Keuangan (OJK) kami sepakat menetapkan bahwa ada kejanggalan pada standar audit keuangan G,"(Victoria, 2019).

Sementara itu, menurut pendapat auditor PT. G menyatakan bahwa " Pengakuan pendapatan atas hak layanan konektivitas kepadaPT. Msesuai dengan ketentuan akuntansi yang berlaku" (Ayuningtyas, 2019). PSAK 23 memberikan regulasi mengenai kriteria pengakuan pendapatan dalam penyusunan laporan keuangan yaitu: 1) pemindahan risiko dan manfaat secara signifikan, 2) jumlah pendapatan dapat diukur secara andal, 3) kemungkinan besar manfaat ekonomi (aruskas masuk) mengalir ke perusahaan (Ikatan Akuntan Indonesia, 2018). Ketiga kriteria tersebutharus dipenuhi, jika salah satu kriteria tidak terpenuhi maka pendapatan belum bisa diakui. Berdasarkan kriteria tersebut dan opini auditor, Manajemen PT. G bersikukuh menyatakan bahwa laporan keuangan PT. G tahun 2018 telah sesuai dengan PSAK 23 (Ibrahim \& Binekasri, 2019). Bahkan Vice President Corporate Secretary PT. G menegaskan bahwa tidak akan ada audit ulang untuk laporan keuangan PT. G tahun 2018 (Kmj, 2019).

Ruang lingkup PSAK No. 23 dapat diterapkan untuk akuntansi pendapatan yang timbul dari transaksi dan keja dian: 1) penjualan barang, 2) penjualan jasa, 3) penggunaan aset entitas oleh pihak lain yang menghasilkan bunga, royalti, dan dividen (Ikatan Akuntan Indonesia, 2018). Dalam kasus PT. G yang diperjualbelikan adalah hak untuk melakukan pemasangan koneksi wifi in flight service. Dalam transaksi tersebut dirasa kurang memadai jika diklasifikasikan sebagai penjualan barang ataupunjasa. Opsi yang ada dalam PSAK 23 selain penjualan barang dan jasa adalah penggunaan aset entitas oleh pihak lain yang menghasilkan bunga, royalti, dan dividen. Namun demikian, karena yang diperjualbelikanadalah hak, maka perlu dilakukan pertimbangan a pakah dalam perjanjian tersebut mengandung sewa atau tidak. Dasar penentuan suatu perjanjian mengandung sewa atau tidak tertuang dalam ISAK 8.

Untuk menentukan apakan suatu perjanjian mengandung sewa atau tidak diperlukan penilaian atas dua aspek yaitu: 1) pemenuhan perjanjian bergantung pada penggunaan suatu aset-aset tertentu, dan 2) perjanjian tersebut memberikan suatu hak untuk menggunakan aset tersebut (Ikatan Akuntan Indonesia, 2018). Saragih (2019) mema parkan jawaban direktur keuangan dan manajemen risiko yang disampaikan oleh PT. Garuda yang menyatakan bahwa perjanjian atara PT. G dengan PT. M bukanlah perjanjian sewa ataupun perjanjian yang mengandung sewa. Untuk itu dalam analisisini menggunakan dasar PSAK 23 dan ISAK 8 dalam penilaian pengakuan pendapatan yang dilakukan.

Berdasarkan PSAK No. 23 (Ikatan Akuntan Indonesia, 2018) Paragraf 20 disebutkan bahwa hasil transaksi dapat diestimasi secara andal apabila memenuhi seluruh kondisi yaitujumlah pendapatan dapat diukur secara andal dan kemungkinan besar manfaat ekonomik sehubungan dengan transaksi tersebut akan mengalir ke entitas. Terkait jumlah pendapatan dapat diukur secara andaldalam perjanjian PT G dengan PT $\mathrm{M}$ jumlah transaksi dapat diukur tetapi tidak memenuhi keandalan. Padahal jumlah tersebut dikatakan andal apabila diungkapkan sesuai fakta, dapat 
dipertanggungjawabkan, dan tidak menyesatkan. Adanya ketidaksesuain jumlah antara pendapatan kompensasi dengan jumlah pendapatan dalam laporan keuangan. Pendapatan kompensasiatas penyediaan layanan konektivitas pada 153 pesawat sebesar U\$D131.940.000. Adapun pendapatan kompensasi terkait hak pengelolaan layanan hiburan dan manajemen konten untuk 99 pesawat senilai U\$D80.000.000. Jumlah total untuk pendapatan kompensasi atas kedua perjanjian kontrak tersebut senilai U\$D211.940.000. Namunjumlah tersebut tidak sesuai dengan yang dicantumkan dalam laporan keuangan tahun 2018 PT G sebesar U\$D239.940.000. Terdapat selisih U\$D28.000.000 yang merupakan bagi hasil dari PT. S tanpa diketahui dasar pembagiannya dan diakui sebagai pendapatan oleh PT G padahal sampai laporan keuangan tahun 2018 diterbitkan belum ada pembayaran dari pihak PT M. Sedangkan dalam laporan keuangan PT G dicantumkan piutang dari PT M sebesar U\$D233.134.000. Hal ini tidak sesuai dengan perjanjian kompensasi yang akan dibayarkan PT M sebesar U\$D211.940.000.

Selanjutnya terkait kebermanfaatan ekonomik yang mengalir ke entitas PT G terkait kerjasama dengan PT M tidak dapat dipastikan dengan jelas. Pada kuartal 1 laporan keuangan tahun2019PT.G dipublikasikan, belum ada keterangan pembayaran apapun yang diterima dari PT. M. Jumlah tagihan yang harus dibayarkan oleh PT. M kepada PT. G memang sudah jelas, namun keandalan dari tagihan tersebut masih kontroversial. Halini terjadi karena ketidakjelasan "term of payment" dalam perjanjian tersebut. Pada perjanjianjuga tidak ada penjelasan secara detail yang mengatur tingkat penyelesaian transaksi kerjasama tersebut.

PT. M dan PT. G melakukan kontrak kerjasama dengan term of payment yang telah diamandemen pada 31 Oktober 2018. Pada tanggal 26 Desember 2018 perjanjian kerjasama tersebut dilakukan amandemen ke dua. Dalam laporan keuangan tidak diungkapkan alasan yang jelas terjadinya amandemen kedua. Hal ini menunjukkan ketidakjelasan pembayaran oleh PT M sesuai dengan yang disampaikan Direktur Penilaian BEI, Y bahwa tidak a da informasi yang detail soal pembayaran dalam kontrak antara PTG dan PT M. Menurutnya, diketahui bahwa dalam kontrak tersebut bagaimana PT M melaksanakan kewajibannya dalam pembayaran penuh dibulan Oktober 2018 saat perjanjian tersebut ditandatangani (Supriyatna \& Fauzi, 2019). Amandemen atas term of payment yang terjadi beberapa kalimenunjukkan bahwa kolektabilitas piutang tersebut rendah. Azka (2019) menjelaskan bahwa pembayaran yang diterima oleh PT. G dari PT. M per 30 Juni 2019 baru sebesar US $\$ 160.000$.

Banjarnahor (2019) menyatakan bahwa PT. M tidak punya teknologi tersebut, dia hanya bertindak sebagai broker sehingga manfaat ekonomik masa depan tidak dapat dipastikan, karena keberhasilan pembayaran yang dilakukan PT. M bergantung pada keberhasilan aplikasi teknologi yang dimiliki oleh pihak ketiga yang tidak bersangkutan dalam pernjanjian antara PT. M dengan PT. G. Dalam penjelasan FR yang merupakan Direktur Manajemen dan Risiko PT. G juga diungkapkan bahwa untuk menjalankan kontrak tersebut PT. M melakukan pendekatan kepada investor dan baru dikonfirmasikan memproleh pendanaan dari pihak lain pada1 Maret 2019. Berdasarkan beberapa kondisi tersebut dapat disimpulkan bahwa kesanggupan PT. M pada tahun 2018 untuk melaksanakan kontrak sangat lemah, dan masih sangat prematur untuk dinilai kemungkinan arus kas masa depan yang akan masuk ke PT. G.

Selanjutnya terkait dengan biaya yang disebabkan terkait transaksi yang berkaitan dapat diukur secara andal. Di masa mendatang belum diketahui biaya yang kemungkinan terjadi atas transaksi perjanjian tersebut. Bahkan tidak ada jaminan yang diberikan oleh PT M terkait transaksi yang dilakukan denganPT G. Berdasarkan kriteria yang harus dipenuhi dalam pengakuan pendapatan sesuai PSAK 23 paragraf 20 maka 
pendapatan dalam perjanjian tersebut seharusnya belum bisa diakui sebagai pendapatan karena hampir semua kriteria tidak da pat dipenuhidalam perjanjian kerjasama tersebut.

Dalamkontrak antara PT G dan PT M hanya diketahui jangka waktu kontrak selama 15 tahun namun tenggang waktu pembayaran tidak dijelaskan secara detail. Padahal dalam perjanjian yang relevan seharusnya hal tersebut dapat diungkapkan secara jelas dan detail. Selain itu berdasarkan hasil pemeriksaan yang dilakukan BEI dikatakan bahwa sampai kuartal I tahun 2019 PT M menemukan kejanggalan baru (Sugianto, 2019a). Kejanggalan tersebut terkait dengan pengakuan awal tetapi tidak diakui penjualan dan colectibility kelayakan dicatatkan sebagai piutang. Manajemen PT.G menyatakan bahwa kolektabilitas pembayaran piutang tidak akan mengakibatkan penyesuaian terha dap pengakuan pendapatan, namunjumlah yang tidak tertagih diakui sebagai beban. Prosedur yang diterapkan tersebut memang sudah sesuai dengan PSAK 23 paragraf 22, namun demikian hal itu dilaksanakan ketika kriteria pengakuan awal pendapatan terpenuhi, sedangkan dalam kasusPT. G pengakuan awal pendapatan tidak memenuhi kriteria karena prematur.

Terdapat landasan konseptual yang tidak boleh dilanggar dalam pengakuan pendapatan. Menurut Suwarjono (2017) konseptual pendapatan hanya dapat diakui apabila keterukurannilai asset (measurability of assetvalue) dapat terpenuhi. Berdasarkan kontrak kerjasama antara PT G dan PT M dapat dilihat dalam kondisi pertama terkait keterukuran nilai asset di mana jumlah rupiah atas transaksi tersebut terbilang sangat besar dan dalam jangka waktu 15 tahun yang diakui dalam 1 periode tahun dinilai tidak objektif dan tidak dapat diuji kebenarannya a pakah di masa mendatang PT M sanggup membayarnya. Padahal jika ditelisik lebih dalam terkait PT M ialah salah satu perusahaan yang masih baru yang didirikan berdasarkan akta nomor 3 November 2017 yang disahkan dalam surat keputusan Nomor AHU- 0140899. AH. 01.11 tahun 2017 pada tanggal8 November 2018 (Melani, 2019). Selainitu ketika menelusuri terkait PT M melalui website perusahaan tersebut belum bisa diakses dan tertulis domain is for sale. Selain itu dalam perjanjian tersebut juga tidak ada jaminan yang diberikan oleh PT M, padahal dalam perjanjian yang bernilai besar tersebut jaminan dalam suatu perjanjian seharusnya ada dan dicantumkan. Selainitu, terkait adanya transaksiseharusnya dalam perjanjian tersebut dalam pengakuan pandapatan harus terdapat transaksi yang dilakukan oleh kedua belah pihak, tetapi sampaikuartal Ijuga belum terdapat transaksi yang dilakukan oleh PT M.

Dalam proses penghimpunan secara substansial telah selesai seharusnya subtansial yang dimaksud dalam perjanjian tersebut telah selesai sehingga pada saat penyerahan hak pendapatan benar- benar bisa diakui. Namun kenyataannya dalam perjanjian tersebut diungkapkan bahwa "term of payment" masih dalam negosiasi yang artinya perjanjian tersebut belum selesai hingga terdapat pengakuan pendapatan oleh PT G.

Dalam laporan keuangan tahun2018 PT G mengakui pendapatan atas transaksi yang timbul akibat perjanjian kerjasama dengan PT Msebagai pengakuan penuh dengan akrual basis. Perjanjian kontrak tersebut disepakati selama 15 tahun, sehingga kontrak tersebut dapat dikategorikan sebagai kontrakjangka panjang. Menurut Riahi \& Belkaoui (2011) pendapatan diakui dengan dasar akrual apabila pendapatan dilaporkan selama produksi (dalam kasus di mana laba dapat dihitung secara proporsional terhadap pekerjaan yang diselesaikan atau jasa yang dilakukan), pada akhir produksi, pada saat penjualan produk, atau pada saat penagihan penjualan. Berdasarkan pengertian tersebut pendapatan yang timbul dari perjanjian tersebut seharusnya belum bisa diakui sepenuhnya sebagai pendapatan karena hingga akhir periode tahun 2018 PT G belum menerima pembayaran dan ketidakjelasan alasan diakui sebagai piutang. Padahal dalam 
kontrak tersebut dijelaskan bahwa pembayaran akan diserahkan setelah penandatanganan kontrak yang dilakukan pada bulan Oktober 2018.

Selain itu Riahi \& Belkaoui (2011) juga menyebutkan dalam pengakuan pendapatan atas kontrakjangka panjang diakui berdasarkan kemajuan konstruksi atau "persentase penyelesaian". Di mana dalam persentase penyelesaian ini dihitung melalui estimasi teknik dari pekerjaan yang dilakukan sampai tanggal tersebut dibandingkan dengan total pekerjaan yang akan diselesaikan dalam hal kontrak. Dalam perjanjian antara PT G dengan PT M menggunakan sistem slot akan tetapi tidak disebutkan kejelasan waktu kapan pemasangan penyediaan konektivitas akan dilakukan. Berikutnya berdasarkan total biaya yang terjadi sampai tanggal tersebut dibandingkan dengan keseluruhan biaya yang diestimasi untuk total proyek di dalam kontrak tersebut. Dalam kontrak yang terjalin antara PT G dan PT M hanya disebutkan biaya yang yang harus dibayarkan setiap tahunnya sejak penerbangan perdana, atas pendapatan aktual yang diperolehnya. Akan tetapi persentase slot dalam perjanjian antara PT G dengan PT M tidak dijelaskan yang mendasari kenaikan persentase setiap tahunnya. Selain itu alokasi slot dalam perjanjian untuk tahun ke-11 sampai 15 belum ditentukan.

Berdasarkan kriteria di atas maka dapat disimpulkan jika PT G seharusnya belum dapat mengakui pendapatan atas perjanjian antara PT G dengan PT M. Hal ini didasarikarena dua kriteria dalam pengakuan pendapatan atas kontrak jangka panjang tersebut belum dapat diestimasi secara pasti dan belum ada kemajuan konstruksi yang dilakukan oleh PT M.

Penolakan penandatangan laporan keuangan oleh dua komisaris tersebut juga menjadi polemik tersendiri bagi PT G. Pasalnya terdapat ketidaksesuaian pendapat antara Direktur Keuangan dengan dua komisaris PT G. Namun penolakan tandatangan tersebut tidak dimuat dalam laporan keuangan tahun 2018 PT G.

Berdasarkan teori keagenan memberikan asumsi bahwa konflik kepentingan akan timbul a pabila setiapindividu termotivasi untuk kepentingan dirinya sendiri. Hal ini memberikan dasar bagi manajer untuk menciptakan konflik keagenan guna mengupayakankeuntungan pribadi daripada memaksimalkan nilai pemegang saham, sehingga terjadi perbedaan prospek pemilik dan kepentingan manajer atau bias dikatakan konflik yang digariskan oleh teori klasik mereka tentang pemisahan kepemilikan dari control (Javaid \& Javid, 2017).

Kecurangan dalam laporan keuangan terjadi karena manajer (agen) mempunyai informasi yang lebih daripada prinsipal. Dalam teori keagenan, agen melakukan kecurangan karena adanya peluang yang tidak akan diketahui oleh prinsipal. Faktor lain yang mendorong tindak kecurangan dalam penyusunan laporan keuangan adalah adanya tekanan dari prinsipal kepada agen untuk mencapai target kinerja keuangan tertentu. Agen akan berupaya menunjukkan kinerja terbaiknya walaupun kadang dengan melakukan praktik akuntansi kreatif yang kurang beretika.

Menurut (Sugianto, 2019) PT G mempercantik laporan keuangan tahun 2018 yang di kuartal III tahun 2018 masih mengalami rugi mendadak saat tutup buku tahun 2018 perusahaan mengalami laba yang nilaicukup signifikan. Darikonflik tersebut dapat diketahui bahwa jika kemungkinan terdapat kepentingan pribadi. Pasalnya Direktur Keuangan PT G bersikukuh mengakui pendapatan bahkan mendukung opini auditor yang mengatakan Wajar Tanpa Pengecualian.

Berdasarkan analisis yang telah dilakukan terkait opini auditor PT G tersebut seharusnya belum bisa diakuiWajar Tanpa Pengecualian karena terdapat kejanggalan dalam pengakuan penda patan atas perjanjian kontrak kerjasama antara PT G dan PT M. Opini tersebut merupakan pelanggaran beratyang dilakukan oleh auditor karena dapat memberikan pengaruh pengambilan keputusan yang salah. Dengan demikian akibat pengakuan wajar tanpa pengecualian tersebut, SM (Menteri Keuangan) menjatuhkan 
sanksi pembekuan izin selama 12 bulan kepada Akuntan Publik (AP) dan Kantor Akuntan Publik (KAP) untuk melakukan perbaikan sistem pengendalian mutu (Kementerian Keuangan Indonesian, 2019). Dasar pengenaan sanksi tersebut sesuai Pasal 25 ayat (2) Pasal 27 ayat 1)(Pasal 25 Ayat (2) danPasal 27 Ayat (1) UU Nomor 5 tahun 2011 danPasal 55 Ayat (4) PMK No 154/PMK.01/2017. Dengan pemberian sanksi tersebut dapat dijadikan sebagai salah satu wujud bentuk tanggungjaw ab auditor dalam menerbitkan opininya sehingga tidak ada kode etikauditor yang dilanggar dan menjadi disalahgunakan. Selain itu akibat pengakuan pendapatan tersebut juga menyebabkan berkurangnya kepercayaan investor terhadap laporan keuangan PT G. Hal ini dibuktikan dengan turunnya harga saham PTG. Harga saham PT G diketahui ditutup melemah Rp 22 atau 5,56\% ke level Rp 374 pada perdagangan sesi 1 pasca dilakukannya hasil pemerikasaan laporan keuangan emiten PT G diumumkan (Uly, 2019).

Selain sanksi diberikan kepada Akuntan Publik dan Kantor Akuntan Publik, Otoritas Jasa Keuangan juga memberikan sanksi kepada PT G. Hal ini didasarkankarena penyajianlaporan keuangan tahun 2018 yang harusnya rugi menjadi untung dan tidak mencantumkan dalam laporan keuangan adanya penolakan tanda tangan laporan keuangan tahun 2018 tersebut oleh dua komisari CT dan DO. Berdasarkan hasil pemeriksaanyang dilakukan antara OJK, Kemenkue, PPPK, dan BEI serta pihak terkait lainnya memberikan sanksi kepada PT G untuk melakukan perbaikan laporan keuangan tahun 2018, sanksi administratif berupa denda Rp 100 juta kepada PT G, Direktur, dan Komisaris yang telah menandatangani laporan keuangan tahun 2018 (Otoritas Jasa Keuangan, 2019). Sanksi tersebut berdasarkan dengan Pasal 69 UndangUndang Nomor 8 Tahun 1995 tentang Pasar Modal (UU PM). Peraturan Bapepam dan LK Nomor VIII.G.7 tentang Penyajian dan Pengungkapan Laporan Keuangan Emiten dan Perusahaan Publik, Interpretasi Standar Akuntansi Keuangan (ISAK) 8 tentang Penentuan Apakah Suatu Perjanjian Mengandung Sewa, dan Pernyataan Standar Akuntansi Keuangan (PSAK) 30 tentang Sewa, Peraturan Bapepam Nomor VIII.G.11 tentang Tanggung Jawab Direksi atas Laporan Keuangan. Dengan demikian, segala sanksi tersebut menjadi bukti bahwa PT G belum menerapkan PSAK 23 dalam pengakuan pendapatannya. Hal ini dapat dijadikan evaluasi dalam perlakuan pendapatan yang baik sesuai denganStandar Akuntansi Keuangan agar tidak merugikan pihak lain maupun perusahaan itu sendiri.

Berdasarkan analisis yang dilakukan terhadap perjanjian kerjasama antara PT. G dengan PT. M serta ketentuan dari ISAK 8 mengenai penentuan apakah transaksi mengandung sewa atau tidak, ditemukan bahwa seharusnya kontrak tersebut masuk dalam transaksi yang mengandung sewa. ISAK 8 paragraf 09 menyatakan bahwa ketika suatu pernjanjian memberikan hak untuk menggunakan kepada pembeli atas penggunaan suatu aset, dimana pembeli memiliki kemampuan untuk mengoperasikan aset atau mengarahkan pihak lain untuk mengoperasikan serta memiliki pengendalian atas akses fisik aset, maka perjanjian tersebut mengandung sewa. Pada perjanjian PT. G dengan PT. M, PT. M memiliki hak untuk menggunakan aset PT. G sebagai sarana pemasangan teknologi yang dimiliki PT. M. PT. M juga bisa mengalihkan hak pemasangan teknologi tersebut kepada pihak ketiga karena pada kondisi riilnya PT. M tidak mempunyai teknologi tersebut, hanya bertindak selaku broker.

Selanjutnya untuk transaksi yang mengandung sewa harusnya tidak mengacu pada PSAK 23 namun lebih kepada PSAK 30. Namun demikian dalam PSAK 30 tidak dijelaskan secara eksplisit bagaimanakah kriteria yang dipersyaratkan untuk pengakuan awal pendapatan sewa. Untuk itu IAI telah melakukan adaptasi terhadap standar akuntansi baru untuk memasukkan regulasi terhadap pendapatan yang sebelumnya belum tercukupi dengan standar yang sudah ada melalui penerbitan PSAK 72 pada 
tahun 2018. Namun demikian, PT. G belum menerapkan standar tersebut karena baru diwajibkan untuk implementasi pada tahun 2020.

PSAK 72 merupakan a da ptasi dari IFRS 15 yang mengatur mengenai pendapatan dari kontrak dengan pelanggan. Regulasi in baruakan diberlakukan secara efektif per 1 Januari 2010. PSAK 72 menggantikanPSAK23, PSAK34, ISAK10, ISAK21, ISAK 27 dan PSAK 44 dengan penerapan awal diperbolehkan. PSAK 27 merupakan proyek kerjasama antara IASB dan FASB. Prinsip utama dari PSAK72 adalah pendapatan itu harus diakui ketika (atau sebagai) entitas mentransfer kendali atas barang ataujasa kepada pelanggan dengan jumlah yang diharapkan menjadi hak entitas. Transfer dapat dianggap terjadi pada suatu titik waktu atau dari waktu ke waktu tergantung apakah kriteria tertentu dipenuhi (Holzmann \& Munter, 2014).

Untukitu diperlukan studi lanjutan apakah penerbitan regulasi baru (dalam hal ini PSAK 72) sudah cukup untuk menangani praktik akuntansi kreatif berupa pengakuan pendapatan prematur seperti yang terjadi pada PT. G ataukah perlu adanya pengaturan lebih lanjut yang melibatkan beberapa pihak terkait untuk merevisi pedoman tata kelola perusahaan yang baik. Di samping itu perlunya penguatan pendidikan etika dalam lingkungan akademik, karena pembentukan karakter yang kuat akan membentuk generasi akuntan yang semakin berintegritas di masa yang akan datang.

\section{SIMPULAN}

PT G telah menerapkan Standar Akuntansi Keuangan dalam Laporan Keuangannya. Kebijakan tersebut salah satunya dalam hal perlakuan akuntansi dalam pengakuan pendapatan. Akan tetapi penerapan PSAK 23 dalam pengakuan pendapatan yang akibat perjanjian antara PT G dengan PT M belum sesuai dengan Standar Akuntansi Keuangan. Hal ini dikarenakan syarat dalam pengakuan pendapatan yang didasarkan pada PSAK 23 Paragraf 28, Paragraf 29, dan Paragraf 30 belum terpenuhi. Kriteria tersebut adalah kemungkinan besar manfaat ekonomik suatu transaksi akan mengalir ke entitas, jumlah dapat diukur dengan andal masih belum diketahui kejelasan yang detail terkait kontrak kerjasama yang dilakukan.

Pengakuan pendapatan PT G dalam laporan keuangan tahun 2018 tersebut juga ditolak oleh dua komisaris yang menyebabkan polemik bagi PT G. Pasalnya dalam pengakuan tersebut terjadi perbedaan pendapat antara Direktur Keuangan dan Komisaris, CT dan DO. Adanya perbedaan tersebut maka erat kaitannya dengan teori keagenan yang menyebutkan bahwa ada perbedaan kepentingan antara pemberi wewenang dan penerima wewenang.

Berdasarkan hal tersebut, peneliti menemukan hasil temuan baru bahwa dalam pengakuan pendapatan yang tidak tepat terdapat teori keagenan yang kemungkinan menjadi alasan perusahaan melakukan pelanggaran. Sehingga sesuai dengan teori keagenan diperlukan pemisahan manajerial antara pemberi wewenang dan yang menerima wewenang. Hal ini dikarena agar tidak ada pihak- pihak yang dirugikan ketika perusahaan melaporkan laporan keuangannya sehingga kepercayaan investor tidak berkurang.

Peneliti menyadari bahwa dalam penelitian ini memiliki keterbatasan tidak semua kasus pengakuan pendapatan dianalisis. Peneliti hanya menganalisis pengakuan pendapatan terkait perjanjian kerjasama PT G dengan PT M. Peneliti juga menyadari bahwa mengalami keterbatasan akses data dalam penelitian ini. Untuk penelitian selanjutnya, peneliti berharap untuk dilakukanny 
penelitian yang lebih luas tidak hanya mencakup pengakuan saja tetapi juga pengukuran, pencatatan, dan pengungkapan serta analisis yang lebih mendalam. Penelitian berikutnya juga bisa menyangkut akuntansi keperilakuan dalam pelaporan laporan keuangan PT G serta dapat meninjau ketercukupan regulasi dalam PSAK 72 untuk mengantisipasi praktik akuntansi kreatif dalam pengakuan pendapatan.

\section{REFERENSI}

Ayuningtyas, D. (2019). Kejanggalan Laba Garuda, Auditor Klaim Sudah Sesuai PSAK. Retrieved December 17, 2019, from https://www.cnbcindonesia.com/market/20190506185233-1770821/kejanggalan-laba-garuda-auditor-klaim-sudah-sesuai-psak

Azka, R. M. (2019). Garuda Indonesia Klaim Mahata Aero Baru Bayar US\$160.000. Retrieved December 20, 2019, from https://ekonomi.bisnis.com/read/20190630/98/939446/garudaindonesia-klaim-mahata-aero-baru-bayar-us160.000

Banjarnahor, D. (2019). Mahata, Broker Teknologi di Balik Keuntungan Garuda pada 2018. Retrieved December 19, 2019, from https://www.cnbcindonesia.com/market/20190424192452-1768683/mahata-broker-teknologi-di-balik-keuntungan-garuda-pada2018

Goel, S. (2019). Ethical Accounting: The Driver in Recovering Markets. Eurasian Studies in Business and Economics, 10(1), 95-106. https://doi.org/https://doi.org/10.1007/978-3-030-11872-3_7

Gowthorpe, C., \& Amat, O. (2005). Creative Accounting : Some Ethical Issues of Macro- and. Journal of Business Ethics, 57, 55-64. https://doi.org/10.1007/s10551-004-3822-5

Hendartyo, M. (2019). Bpk temukan dugaan rekayasa dalam laporan keuangan garuda.

Holzmann, O. J., \& Munter, P. (2014). New Revenue Recognition Guidance. Wiley Periodicals, Inc, 73-76. https://doi.org/10.1002/jcaf

Ibrahim, I., \& Binekasri, R. (2019). Garuda Indonesia Bersikukuh Laporan Keuangan 2018 Tak Langgar PSAK 23. Retrieved December 17, 2019, from

https://www.jawapos.com/ekonomi/bisnis/30/04/2019/garudaindonesia-bersikukuh-laporan-keuangan-2018-tak-langgar-psak-23/

Ikatan Akuntan Indonesia. (2018). Standar akuntansi keuangan. Jakarta: Salemba Empat.

Javaid, H. M., \& Javid, S. (2017). Determining agency theory framework through financial leverage \& insider ownership. International Journal of Economics and Finance, 9(3), 21-28. https://doi.org/10.5539/ijef.v9n3p2

Kementerian Keuangan Indonesian. (2019). Menkeu jatuhkan sanksi auditor laporan keuangan garuda indonesia.

Kmj. (2019). Kisruh Laporan Keuangan, Garuda: Tidak Ada Audit Ulang. Retrieved December 17, 2019, from https://economy.okezone.com/read/2019/05/03/320/2051194/kisru h-laporan-keuangan-garuda-tidak-ada-audit-ulang 
Melani, A. (2019). Siapa mahata aero teknologi penyedia layanan wifi garuda? Miles, M. B., \& Huberman, A. M. (1994). Qualitative Data Analysis. SAGE Publications (Vol. 2).

Muslimawati, N. (2019). Kemenkeu: ada dugaan audit laporan keuangan garuda tak sesuai standar.

Otoritas Jasa Keuangan. (2019). Siaran pers : otoritas jasa keuangan berikan sanksi kasus pt garuda indonesia (persero )tbk.

Pratiwi, H. R. (2019). Kronologi kisruh laporan keuangan garuda indonesia.

Puranidhi, A. L. W. (2019). Dua komisaris tolak laporan keuangan garuda, ada apa?

Riahi, A., \& Belkaoui. (2011). Accounting theory. Jakarta: Salemba Empat.

Saragih, H. P. (2019). 10 Jawaban Garuda Terkait Janggalnya Laba \& Misteri Mahata. Retrieved December 18, 2019, from https://www.cnbcindonesia.com/market/20190506171406-1770803/10-jawaban-garuda-terkait-janggalnya-laba-misteri-mahata

Simorangkir, E. (2019). Kronologi kisruh laporan keuangan garuda.

Sugianto, D. (2019a). Bei temukan kejanggalan baru laporan keuangan garuda indonesia.

Sugianto, D. (2019b). Garuda disebut "mempercantik" laporan keuangan.

Supriyatna, I., \& Fauzi, A. (2019). Kontrak garuda indonesia dan mahata tak jelas pembayarannya.

Suwarjono. (2017). Teori akuntansi. Yogyakarta: BPFE.

Uly, Y. A. (2019). Laporan keuangan janggal, saham garuda anjlok $5 \%$.

Victoria, A. O. (2019). Sri mulyani: ada kejanggalan pada laporan keuangan garuda indonesia. 